\title{
Galactose-1-Phosphate Uridylyltransferase
}

National Cancer Institute

\section{Source}

National Cancer Institute. Galactose-1-Phosphate Uridylyltransferase. NCI Thesaurus. Code C148334.

Galactose-1-phosphate uridylyltransferase (379 aa, $\sim 43 \mathrm{kDa}$ ) is encoded by the human GALT gene. This protein plays a role in the metabolism of galactose. 